\title{
Synthesis and Secretion of Mutant Mannose-Binding Lectin
}

\author{
Ho-Jung Jang and Kyung Tae Chung*
}

Department of Cinical Laboratory Science, Dong-Eui University, Busan, 614714, Korea

Received February 19, 2013 /Revised March 25, 2013 /Accepted March 26, 2013

\begin{abstract}
Innate immunity is the ability to differentiate infectious agents from self. The innate immune system is comprised of a complicated network of recognition and effector molecules that act together to protect the host in the early stage of an infectious challenge. Mannose-binding lectin (MBL or mannose-binding protein, MBP) belongs to the family of $\mathrm{Ca}^{2+}$-dependent lectins (C-type lectin with a collagen-like domain), which are considered an important component of innate immunity. While it is associated with increased risk and severity of infections and autoimmunity, the most frequent immuno-deficiency syndrome was reported to be low MBL level in blood. Deficiency of human MBL is caused by mutations in the coding region of the $M B L$ gene. Rat homologue gene of human $M B L$ gene was used to study functions of wild type and mutant MBL proteins. Although extensive studies have yielded the structural information of MBL, the functions of MBL, especially mutant MBL, still require investigation. We previously reported the cloning of rat wild-type $M B L$ gene and the production of a truncated form of MBL protein and its antibody. Here, we present the cloning of mutant $M B L$ cDNA in collagen-like domain (R40C, G42D, and G45E) using site-directed mutagenesis and differential behaviors of wild type and mutant MBL in cells. The major difference between wild type and mutant MBL was that while wild type MBL was secreted, mutant MBL was inhibited for secretion, retained in endoplasmic reticulum, and still functioned as a lectin.
\end{abstract}

Key words : Endoplasmic reticulumn Secretion, Genetic disease, Immunodeficiency, Mannose-binding lectin

\section{서 론}

혈액에 존재하는 mannose binding lectin (MBL)은 C-type lectin의 super family에 속하는 collectin 단백질의 일종으로서 선천성 면역을 구성하는 중요한 분자에 속한다. MBL은 병원 성 세균, 바이러스, 원생생물, 균류 등에 존재하는 mannose를 함유하는 탄수화물의 pattern을 인식하여 self와 nonself를 구 별하는 기능을 가지고 있다[11, 14, 26]. MBL은 미생물 표면에 결합하여 항체와 $\mathrm{C} 1$ 의존적인 보체 결합 반응을 유발하며, 식 세포의 세포 표면 receptor와 직접적으로 결합하여 보체 작용 없이 opsonophagocytosis를 촉진 할 수도 있다[13]. 이러한 기 능을 가진 $\mathrm{MBL}$ 은 병원균 감염 후 초기 몇 시간 내지 몇 일의 일차면역 반응에 중요한 역할을 하며, 획득 면역이 작용하기 전에 제일선의 방어를 제공하고, 특히 획득면역이 미성숙한 시기인 영아기에 있어서 중요한 역할을 한다[2, 6, 8, 34].

$\mathrm{MBL}$ 분자의 monomer 구조는 짧은 $\mathrm{N}$-말단 영역에 보존된

\footnotetext{
*Corresponding author

Tel : +82-51-890-2681, Fax : +82-51-890-2622

E-mail : kchung@deu.ac.kr

This is an Open-Access article distributed under the terms of the Creative Commons Attribution Non-Commercial License (http://creativecommons.org/licenses/by-nc/3.0) which permits unrestricted non-commercial use, distribution, and reproduction in any medium, provided the original work is properly cited.
}

cysteine 잔기를 가지고 있으며 이것은 trimer와 그 이상의 oligomer를 형성 할 때 이황화 결합을 형성하는 중요한 역할 을 하는 것으로 알려져 있다. 그 다음으로 Gly-X-Y의 세 아미 노산의 반복되는 콜라겐 유사부분과 C-말단에 탄수화물 인식 영역인 lectin domain (carbohydrate-recognition domain, CRD) 이 존재한다. 3 개의 monomer polypeptide는 Gly-X-Y 반복 부위를 통해 콜라겐과 같은 triple-helical 구조를 형성한 다. 또한, C-말단의 148 155 아미노산은 짧은 목 부분을 이루 며, $\mathrm{CRD}$ 는 독자적인 구형의 C-말단 구조를 형성한다[1, 32]. 이 trimer 6 개가 다시 결합하여 hexamer를 이루며 hexamer는 튤립 다발과 같은 구조를 형성하는 것으로 알려져 있다.

사람 $M B L$ 유전자는 $M B L 2$ 라고 명명되며 10 번 염색체에 존 재한다. 사람은 $M B L 2$ 유사 유전자인 $M B L 1$ 도 존재 하지만 $M B L 1$ 유전자는 exon 3번과 4번에 nonsense 돌연변이인 stop codon이 존재하고 있으며 intron 1 번의 splicing 결여로 발현 되지 않는다[35]. MBL의 결핍은 소아에서 반복되는 상기도 감염, 중이염, 만성 설사를 유발하는 등 빈번한 미생물 감염을 초래하고 만성 염증성 질환에 대한 감수성이 높은 면역 결핍 상태를 유발한다고 보고되어 있다 $[18,21] . \mathrm{MBL}$ 의 결핍은 $M B L 2$ 유전자에 한 개의 점돌연변이가 원인으로 알려져 있으 며, 이 점돌연변이는 각각 다른 3 개 아미노산이 치환된 3 종류 가 존재한다. 세 종류의 각각 점돌연변이는 정도의 차이는 있 으나 모두 세포 밖으로의 분비 이상을 유발하는 것으로 알려 
져 있다. 이로 인해 결과적으로 혈액 내 $\mathrm{MBL}$ 의 농도가 낮아져 MBL 결핍이 발생한다.

$M B L 2$ 유전자는 4 개의 불연속적인 exon으로 구성되어 있 으며 쥐의 homologue 유전자인 $M B L-A$ 는 $M B L 2$ 와 같이 4 개 의 불연속적인 exon 영역을 가지며 각각의 exon은 $M B L 2$ 와 동일한 영역을 coding하고 있다. 쥐 $M B L-A$ 유전자에서 생산 된 MBL 단백질 역시 혈액에 존재하며, 기능적으로도 동일하 게 세균과 결합한다[16]. 이러한 이유로 사람 $\mathrm{MBL}$ 의 생화학적 특성 연구를 위해 쥐 $M B L-A$ 유전자를 사용하는 경우가 많으 며 본 실험에서도 쥐 $M B L-A$ 를 실험에 사용하였다. 알려져 있는 MBL의 돌연변이는 N-말단 쪽의 콜라겐 유사부분에 발견되는 Arg40Cys, Gly42Asp, Gly45Glu의 세 종류가 있다[21, 37].

선행 연구에서 Sprague Dawley rat의 간조직을 적출하여 추출한 RNA에서 정상 $M B L-A$ 의 $\mathrm{cDNA}$ 를 제조하였다[22]. 본 연구에서는 정상 $M B L-A$ 을 이용하여 선천성 면역 결핍증과 관련된 $\mathrm{MBL}$ 의 돌연변이 유전자를 제조 하였으며, 돌연변이 MBL 단백질의 세포 내 생산과 분비에 대해 조사하였다. 돌연 변이 MBL 단백질은 세포 내에서 정상 MBL 단백질과 거의 동일하게 세포 내에서 생산되었으며, 기존에 보고된 것과는 달리 lectin 기능에도 정상 $\mathrm{MBL}$ 과 별다른 차이를 나타내지 않았다. 그러나 정상 MBL 단백질은 세포 밖으로 분비가 되나 돌연변이 MBL 단백질은 분비가 억제되는 것을 확인하였다. 이러한 세포 내 생산과 lectin 기능에는 차이는 없으나, 세포 밖 분비에 현격한 차이를 가진 돌연변이 $\mathrm{MBL}$ 을 확보함으로써 향후 분비 메카니즘 연구를 통한 선천성 면역결핍에 대한 연 구에도 큰 기여를 할 것으로 생각된다.

\section{재료 및 방법}

Wild type MBL-A와 Triple Mutant MBL-A 유전자 Cloning

$M B L-A$ CDNA는 Kwon [22] 등이 클로닝한 것을 사용하였 다. 간단히 서술하면 Sprague Dawley rat의 간조직으로부터 추출한 $\mathrm{RNA}$ 에서 Superscript $\Pi^{\mathrm{TM}}$ reverse transcriptase (Invitrogen)를 사용하여 cDNA를 제조하였다. 제조된 cDNA 를 주형으로 하여 $B a m H$ 과 Xhd 제한효소 서열을 함유한 forward primer와 reverse primer를 사용하여 $\mathrm{PCR}$ 을 실시하고,
pGEM-T vector (Promega)에 삽입하여 pGEM rMBL을 제조 하였다. 이때 발현벡터에서 HA tagging을 위하여 reverse primer에 stop codon을 제거하였다.

Mutagenesis는 GeneTailor ${ }^{\mathrm{TM}}$ Site-Directed Mutagenesis System (Invitrogen) Kit을 사용하였다. 사용자 매뉴얼에 따라 돌연변이에 필요한 primer를 제작하였으며(Table 1) 각 primer set를 사용하여 single point mutation을 유발시킨 후 순 차적으로 2차, 3 차 single point mutation을 추가적으로 유발 시킴으로써 3 개의 점돌연변이가 연속으로 존재하는 triple mutant $M B L-A$ cDNA를 구축하였다. 완성된 triple mutant $M B L-A$ cDNA는 $B a m H$ 와 $X h d$ 로 절단하여 동일한 제한효소 로 절단한 DSL-HA vector에 삽입 하였다. 구축한 모든 $\mathrm{CDNA}$ 는 DNA 염기서열 분석 회사인 (주)솔젠트사에서 DNA 염기 분석으로 DSL-HA vector에 삽입과 HA-tagging 여부를 확인 하였다.

SDS-PAGE 및 Western blot 방법을 사용한 MBL 단백 질 분석

$M B L$ 의 단백질 발현 관찰을 위해 $\mathrm{HeLa}$ 세포는 $100 \mathrm{~mm}$ dish에 $2.5 \times 10^{6}$ cells/dish 로 배양하였다. 배양 18 시간 후, wild type $M B L-A$ 과 triple mutant $M B L-A$ DNA을 Lipofectamin 2000 reagent (Invitrogen)을 사용하여 형질전환 하였으며, 형 질전환 48 시간 후, NP-40 lysing buffer $(50 \mathrm{mM}$ Tris- $\mathrm{HCl}$, $\mathrm{pH} 7.5,150 \mathrm{mM} \mathrm{NaCl}, 0.5 \% \mathrm{DOC}$, and $0.5 \% \mathrm{NP}-40$ )로 세포를 용해시키고, $4^{\circ} \mathrm{C}$ 에서 $12,000 \mathrm{rpm}$ 으로 10 분간 원심분리하여 고형성분을 제거한 cell lysate를 회수하였다. Cell lysate에 존 재하는 MBL 단백질 분석은 $12 \%$ polyacrylamide gel을 사용 하여 SDS-PAGE와 western blot으로 하였다. SDS-PAGE 실시 후 Transfer electrophoresis unit (Amersham)을 이용하여 250 $\mathrm{mA}$ 에서 3 시간 동안 nitrocellulose membrane으로 단백질을 전이 시키고, gelatin buffer $(0.1 \%$ Gelatin, $15 \mathrm{mM}$ Tris- $\mathrm{HCl}$ $\mathrm{pH}$ 7.5, $1 \mathrm{mM}$ EDTA, 0.1\% Triton X-100, $130 \mathrm{mM} \mathrm{NaCl}$ )를 사용하여 $40^{\circ} \mathrm{C}$ 의 진탕수조에서 30 분간 blocking 하였다. MBL 단백질은 mouse anti-HA monoclonal antibody (Roche, 1: 500)를 18 시간 반응 시킨 후, 항체를 제거하고 Tris-saline wash buffer (1 mM Tris-HCl pH 7.5, 0.9\% NaCl) 및 Tris-sal-

Table 1. Primer sequences used for site-directed Mutagenesis

\begin{tabular}{cll}
\hline Genes & \multicolumn{1}{c}{ Sequences } \\
\hline \multirow{2}{*}{ R40C } & $\begin{array}{l}\text { sense } \\
\text { antisense }\end{array}$ & $\begin{array}{l}\text { TAGCCTGCGGCAGAGACGGGTGTGATGCCAA } \\
\text { CCCGTCTCTGCCGCAGGCTATCACAGA }\end{array}$ \\
\hline \multirow{2}{*}{ G42D } & sense & GCGGCAGAGACGGGAGAGATGATCCCAGGGA \\
& antisense & ATCTCTCCCGTCTCTGCCGCAGGCTAT \\
\hline \multirow{2}{*}{ G45E } & sense & ACGGGAGAGATGGGCCCAAAGAGGAGAGAGA \\
& antisense & TTTGGGCCCATCTCTCCCGTCTCTGCC \\
\hline
\end{tabular}

Mutation site 
ine-Triton X-100 wash buffer ( $1 \mathrm{mM}$ Tris- $\mathrm{HCl} \mathrm{pH}$ 7.5, 0.9\% $\mathrm{NaCl}, 0.05 \%$ Triton X-100)를 사용하여 각각 30 분간 nitrocellulose membrane을 씻어 주었다. 그 후 goat anti-mouse IgG peroxidase (Sigma 1:1,000)를 사용하여 실온에서 1 시간 반응 시켰다. 반응 후, 동일한 wash buffer를 사용하여 30 분간 씻어 준 다음 ECL Plus chemiluminescence reagent (Amersham Pharmacia Biotech)로 반응시키고 X-ray film에 감광하여 단백질을 확인하였다.

Immunoprecipitation (면역침강)은 $1 \mu \mathrm{g}$ anti-HA antibody 와 $50 \mu \mathrm{l}$ protein $\mathrm{A}$ agarose를 cell lysate에 첨가하고 $4^{\circ} \mathrm{C}$ 에서 2 시간 동안 회전시키면서 실시하였다. Protein A agarose bead는 6,000 rpm에서 3 분간 원심분리하여 회수하고 NP-40 lysing buffer로 3 회 씻어 준 후 $30 \mu$ SDS-PAGE loading buffer를 첨가하였다. 이후 SDS-PAGE를 실시하고, 상기와 같은 방법으로 western blot을 하였다.

Mannan-Agarose를 사용한 MBL의 Lectin 기능 검증과 세포 밖 분비 차이 분석

MBL의 lectin domain의 기능 검증과 wild type과 mutant $\mathrm{MBL}$ 단백질의 세포 밖 분비 차이를 관찰하기 위해, $\mathrm{HeLa}$ 세 포를 $100 \mathrm{~mm}$ dish에 $2.5 \times 10^{6}$ cells/dish 로 배양하였다. 배양 18 시간 후, wild type MBL- $A$ 과 triple mutant MBL-A DNA를 Lipofectamin 2000 reagent (Invitrogen)을 사용하여 형질전환 하였으며, 형질전환 48 시간 후, NP-40 lysing buffer 처리로 얻은 cell lysate와 각각의 배지를 회수 하였다. 회수한 $200 \mu \mathrm{l}$ cell lysate에는 $1 \mathrm{ml}$ loading buffer (50 mM Tris-HCl pH 7.5, $125 \mathrm{mM} \mathrm{NaCl}, 25 \mathrm{mM} \mathrm{CaCl}$ )를 첨가하고, 회수한 $1 \mathrm{ml}$ 배지 에 $1 \mathrm{M} \mathrm{CaCl}_{2}$ 를 $25 \mu \mathrm{l}$ 넣었다. Mannan-agarose (Sigma)는 loading buffer를 사용하여 3 번 씻어준 후, cell lysate와 배지 에 각각 $50 \mu 1$ 씩 넣어 $4^{\circ} \mathrm{C}$ 에서 1 시간 동안 회전하면서 반응시 켰다. 반응 후, mannan-agarose bead를 회수하여 동일한 loading buffer로 3 번 씻어 준 다음, $12 \%$ polyacrylamide gel 을 사용하여 SDS-PAGE 를 실시하고, western blot을 실시하 여 mannan-agarose bead에 결합된 단백질을 확인하였다.

\section{$\operatorname{COS}$ 세포 내 발현된 MBL 단백질의 Immunohistochemistry}

$M B L-A$ 의 단백질 발현 관찰을 위해 $35 \mathrm{~mm}$ dish에 $24 \times 24$ $\mathrm{mm}$ coverslip을 넣은 후, $\operatorname{COS}$ 세포를 $4 \times 10^{5}$ cells/dish로 배양 하였다. 배양 18 시간 후 wild type과 triple mutant MBL-A를 Lipofectamin 2000 reagent (Invitrogen)를 사용하여 형질전환 하였으며, 형질전환 48 시간 후, 세포를 $4 \%$ formaldehyde로 20 분 동안 실온에서 고정시켰다. 고정이 끝난 후, $\mathrm{PBS}$ 를 사용 하여 3 번 씻고 blocking buffer $(0.1 \%$ Dry milk $+0.1 \%$ sodium azide)로 1 시간 처리하였다. 1차 항체로 mouse anti-HA (Roche, 1:200)를 사용하였으며, 실온에서 18 시간 반응시킨 다음 blocking buffer로 3 번 씻어 주었으며 2차 항체 goat an- ti-mouse IgG FICT (Rockland 1:200)를 처리하여 실온에서 1 시간 반응 시켰다. 2 차 항체를 제거하고 $\mathrm{PBS}$ 를 사용하여 3 번 씻었다. Coverslip은 vectashield를 사용하여 mounting 하 였으며 Motic AE 31 형광 현미경 이미지 시스템을 통하여 형 광을 관찰하였다.

\section{결 과}

Site-directed Mutagenesis system을 사용한 mutant $\mathrm{MBL}$ 제조

$\mathrm{MBL}$ 유전자에 존재하는 돌연변이로 인한 MBL 단백질의 비정상적인 기능 연구를 위하여 Kwon [22] 등이 클로닝한 $M B L-A \mathrm{CDNA}$ 를 주형으로 사용하여 세 종류의 점돌연변이를 GeneTailor $^{\mathrm{TM}}$ Site-Directed Mutagenesis System (Invitrogen) $\mathrm{Kit}$ 을 사용하여 도입하였다. 사람의 경우 $\mathrm{MBL}$ 의 돌연변이는 Arg40Cys, Gly42Asp, Gly45Glu 세 곳의 위치에 각각 존재하 는 것으로 알려져 있으며, 이들 세 곳에 대응되는 쥐의 $M B L-A$ 염기위치에 3 개의 point mutation 함께 존재하는 triple mu$\operatorname{tant} M B L-A$ 을 제작하였다. Mutagenesis의 primers의 합성은 $5^{\prime}$ primer (sense)는 돌연변이 염기가 치환된 서열이 포함되게 제작하고, 3' primer (antisense)가 5' primer와 일부 overlapping 되도록 디자인 하였다(Table 1). Triple mutation은 각 각의 점돌연변이를 순차적으로 도입하여 제작하였다. 즉, 먼 저 $\mathrm{Arg} 40 \mathrm{Cys}$ 로 치환된 점돌연변이 $\mathrm{DNA}$ 를 제작한 후, 이를 주형으로 Gly42Asp 돌연변이를 추가로 도입하였으며, 다시 두 개의 돌연변이가 존재하는 $\mathrm{DNA}$ 를 주형으로 하여 Gly45Glu의 돌연변이를 최종적으로 도입하였다. 각 단계별로 DNA sequencing을 실시하여 돌연변이 도입 여부를 확인하였 다. PCR product를 BamH 과 $X \mathrm{hd}$ 를 사용하여 절단하였고 동일한 제한효소로 절단한 DSL-HA vector에 클로닝하였다. 클로닝한 지도와 돌연변이가 도입된 부분의 염기서열을 Fig. 1 에 나타내었다.

\section{세포에서 wild type과 triple mutant MBL 단백질 발현 확인}

$35 \mathrm{~mm}$ tissue culture plates에 HeLa cello이 $4 \times 10^{5}$ cells/dish 되게 seeding하여 $2 \mathrm{ml}$ 의 DMEM ( $10 \%$ fetal bovine serum, 10,000 $\mathrm{U}$ of penicillin $\mathrm{g} / \mathrm{ml}$, streptomycin 100 $\mu \mathrm{g} / \mathrm{ml}$ ) 배지를 첨가하여 18 시간 배양한 후, wild type $M B L-A$ 과 triple mutant $M B L-A$ 를 형질전환 하였다. 형질전 환 된 세포에서 생산된 각 단백질을 western blot 방법으로 분석하였다. 형질 전환 2 일 후, 형질 전환된 $\mathrm{HeLa}$ cell의 cell lysate를 NP-40 lysing buffer를 사용하여 회수하였고, 각 cell lysate의 동일 양인 $700 \mu \mathrm{l}$ 을 적용하여 anti-HA와 protein A bead를 사용하여 면역 침강을 시행하였다. 면역침강 후 SDS-PAGE와 western blot을 하고 항체 anti-HA를 사용하여 

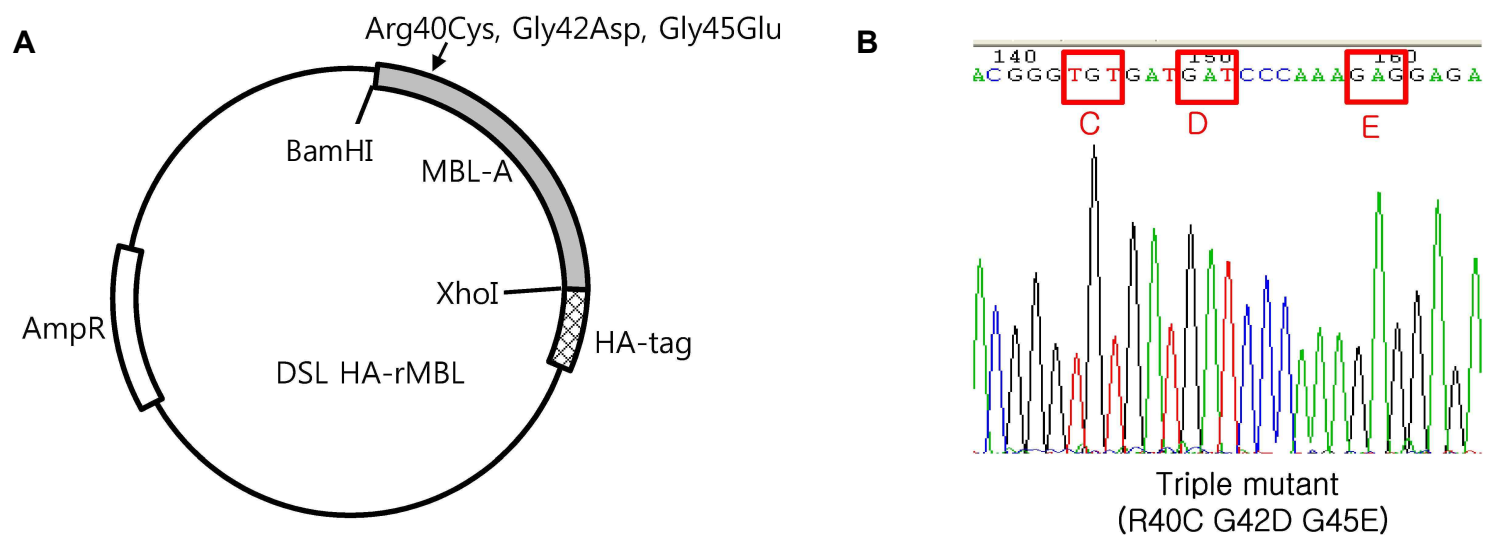

Fig. 1. Construct map of MBL-A and DNA sequencing analysis of triple mutant MBL-A. A. Both wild type and triple mutant MBL-A DNAs were cloned in DSL-HA vector between $B a m H$ and $X h d$ sites and fused with HA tag. B. Electropherogram of triple mutant MBL-A DNA. C: cysteine, D: aspartic acid, E: glutamic acid, G: glycine, R: arginine.

단백질의 발현을 확인하였다. 확인 결과 wild type MBL과 triple mutant $\mathrm{MBL}$ 의 단백질 양이 크게 차이가 나지 않아 정 상과 돌연변이의 단백질 사이에 발현의 차이는 없는 것으로 나타났다(Fig. 2). 다만, triple mutant MBL 단백질 band가 shift 되어 wild type 단백질 보다 size가 높게 나타났는데, 이는 arginine과 2 개의 glycine이 cysteine과 aspartic acid, glutamic acid로 치환되어 분자량이 약간 증가된 것과 치환 된 이들 아미노산이 음이온을 가짐으로써 인산화된 단백질 들이 PAGE에서 mobility shift가 나타나는 것과 같이 shift가 일어난 현상으로 생각된다(Fig. 2).

A

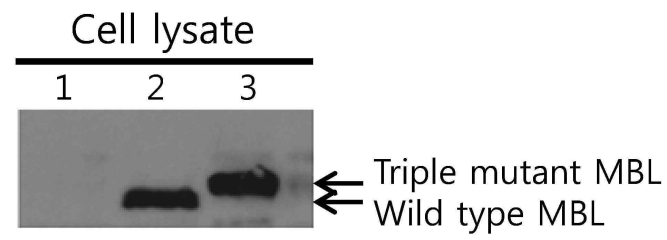

B

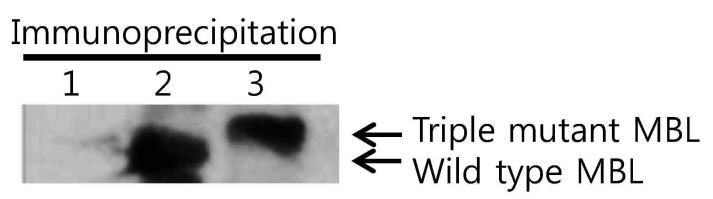

Fig. 2. Synthesis of wild type and triple mutant MBL proteins. Both wild type and triple mutant MBL-A DNAs were expressed in HeLa cells. A. Western blot of cell lysate was done to identify wild type and triple mutant MBL proteins using anti-HA antibody. B. Wild type and triple mutant MBL proteins were immunoprecipitated with anti-HA antibody and analyzed by western blot. Lane 1 : control, lane 2: wild type MBL, lane 3: triple mutant MBL.

\section{Mannan-agarose를 사용한 Lectin의 기능 검증}

Wild type $M B L-A$ 과 triple mutant $M B L-A$ DNA를 HeLa 세포에 형질전환 하고 48 시간 후 cell lysate를 회수하여 mannan-agarose로 침강을 시행하였다. Mannan-agarose에 침강 된 단백질을 anti-HA로 western blot한 결과, 예상한 것과 같 이 wild type MBL이 검출되어 lectin domain이 정상 기능을 하는 것을 확인하였다. 이와 마찬가지로 triple mutant MBL이 mannan-agarose와 함께 침강된 것이 확인되었는데 이는 돌연 변이 위치와 떨어진 C-말단 쪽의 lectin domain이 정상인 구조 를 형성하여 정상적인 기능을 하는 것으로 여겨진다(Fig. 3A. Upper panel).

Wild type과 triple mutant $\mathrm{MBL}$ 단백질의 세포 밖 분비 차이

Wild type MBL과 triple mutant MBL 단백질의 세포 밖 분비의 차이점을 알아보기 위하여 wild type과 triple mutant $M B L \mathrm{DNA}$ 를 $\mathrm{HeLa}$ 세포에 형질전환 하고 48 시간 배양한 후 회수한 각각의 배지를 mannan-agarose로 침강을 시행하여 세 포 밖으로 분비된 MBL 단백질을 검출하였다. Mannan-agarose에 침강된 단백질을 anti-HA로 western blot한 결과, wild type MBL은 band를 확인 할 수 있었지만, triple mutant MBL 은 확인 할 수 없었다(Fig. 3A. Bottom panel). 이것은 wild type MBL이 secretory pathway를 거쳐 세포 밖으로 분비는 것과는 달리 triple mutant MBL은 세포 밖으로 분비가 되지 않음을 나타내며, triple mutant MBL의 lectin domain이 정상 적 기능을 하는 것으로 보아 $\mathrm{N}$-말단 쪽의 돌연변이가 세포 밖으로의 분비와 연관되어 있음을 뜻한다. 분비되지 못하는 triple mutant $\mathrm{MBL}$ 의 세포 분포를 조사하기 위해 wild type $M B L-A$ 과 triple mutant $M B L-A \mathrm{DNA}$ 를 $\mathrm{COS}$ 세포에 형질전 환 하고 anti-HA 항체를 사용하여 immunohistochemistry를 하였다. Fig. $3 \mathrm{~B}$ 에서 보여지는 것과 같이 wild type MBL은 
A
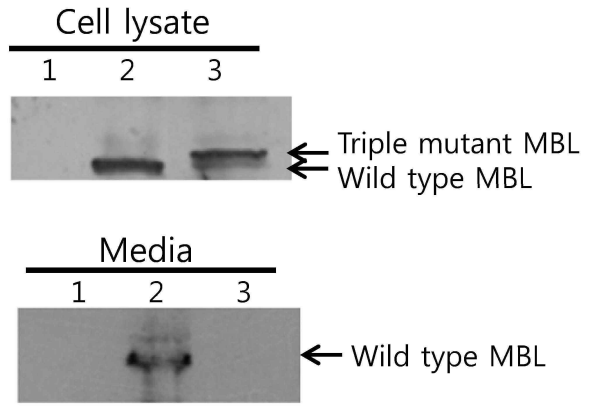

B
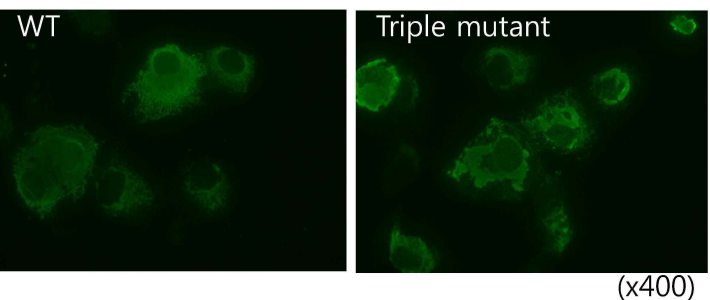

Fig. 3. Mannan-agarose precipitation of wild type and triple mutant MBL. Cell lysate (A upper panel) and media (A bottom panel) from wild type MBL and mutant MBL transfected HeLa cells were precipitated with mannan-agarose beads. Precipitates were separated by SDS-PAGE and analyzed by western blot. Lane 1: control, lane 2: wild type MBL, lane 3: triple mutant MBL. B. Immunostained wild type and mutant MBL showed their localization in endoplasmic reticulumn of COS cells.

세포 내 endoplasmic reticulumn에 존재하며, endoplasmic reticulumn 구조도 정상적으로 망상구조(network)를 유지하 고 있는 것에 반해, triple mutant MBL은 endoplasmic reticulumn에 존재하나 망상구조가 손상된 비정상적인 endoplasmic reticulumn 구조를 나타내었다. 즉, wild type MBL은 endoplasmic reticulumn에서 합성되어 정상적으로 분비됨으로 써 endoplasmic reticulumn network가 정상적인 것과는 달 리, triple mutant MBL은 비록 정상적으로 합성이 이루어지고 있고, lectin 기능도 정상적이나 어떤 이유로 인하여 endoplasmic reticulumn으로부터 더 이상 분비경로를 거치지 못하고 endoplasmic reticulumn 내에 머물고 있음으로써 endoplasmic reticulumn 망상구조가 비정상적인 것으로 보여 진다.

\section{고 찰}

병원성 미생물의 세포 표면 pattern을 인식하여 제일선의 방어체계를 형성하는 선천성 면역은 획득면역이 성숙되지 않 은 영아기에 매우 중요한 역할을 하며 $[5,26,27]$, 어른의 경우 에도 감염 초기에 작용하여 숙주를 보호하는데 커다란 기여를 한다[24, 30]. 혈청 내 $\mathrm{MBL}$ 의 농도는 정상 백인의 경우 $1680 \pm 250 \mathrm{ng} / \mathrm{ml}$ 인데 비하여 면역결핍증 환자의 경우 $19 \pm 8$ $\mathrm{ng} / \mathrm{ml}$ 로 약 80 배 이상이나 낮다 $[3,19,34] . \mathrm{MBL}$ 은 선천성 면 역을 담당하는 중요한 면역인자로서, 면역결핍증을 가지고 있 는 사람은 $\mathrm{MBL}$ 유전자에 돌연변이가 존재하는 것으로 알려져 있다[12, 15, 29]. 예를 들어 류마티스 관절염(rheumatoid arthritis), 전신성 홍반성 루푸스(systemic lupus erythematosus), 스조그렌 증후군(Sjogren's syndrome) 등의 자가 면역질환에 걸린 사람에게서 $\mathrm{MBL}$ 의 유전적 변이에 의한 $\mathrm{MBL}$ 의 혈청 내 농도의 감소가 보고 되어있다[18, 21]. 이 유전 적 결함은 $M B L 2$ 유전자의 콜라겐 유사 domain을 발현하는 exon1에서 일어난 3 개의 점돌연변이 때문인 것으로 유전학적 연구를 통하여 밝혀졌다[29,36]. 이 돌연변이로 인해 $M B L$ 은 기능적인 multimeric protein으로 조립되지 못하여 carbohydrate recognition domain은 정상인데도 불구하고 콜라겐 domain이 돌연변이인 비기능적인 MBL protein을 형성하게 된 다 $[17,25] . \mathrm{MBL}$ 의 낮은 혈청 농도로 인한 면역결핍증은 유전 학적 연구는 많이 진행되었으나 분자 세포 생물학적 원인은 아직도 연구되어야 할 부분이 많이 남아 있다[14, 31]. 쥐의 $M B L$ 유전자는 사람의 $M B L 2$ 유전자와 상동성이 높아 사람 MBL의 연구 모델로 많이 사용되고 있다 $[6,10,34] . M B L 2$ 내에 서 발견되는 세 개의 점 돌연변이를 쥐 $\mathrm{MBL}$ 단백질에 도입하 기 위해 MBL-A 유전자가 선행 연구로 구축 되었다. 본 연구에 서는 혈청 내 $\mathrm{MBL}$ 의 농도가 낮은 이유가 mutant MBL이 소포 체 내에서 정상적인 folding과 assembly가 되지 않고 ER quality control에 의해 통제 되어 분비 되지 않는다는 가설을 알아 보기 위해 돌연변이 $M B L$ 을 제작하였으며, mutant MBL의 축 적이 유발하는 세포의 반응 과정을 알아보고자 하였다. Wild type $M B L$ 을 주형으로 하여 GeneTailor ${ }^{\mathrm{TM}}$ Site Directed Mutagenesis System을 이용하여 사람의 MBL2 유전자에서 발 견되는 점돌연변이인 $\mathrm{Arg} 40 \mathrm{Cys}, \mathrm{Gly} 42 \mathrm{Asp}, \mathrm{Gly} 45 \mathrm{Glu}$ 를 쥐의 유전자에 대응되는 동일한 위치에 도입하여, 세 종류의 돌연 변이를 모두 가지고 있는 triple mutant MBL 제작하여, mutant와 wild type MBL을 비교하였다. 세 종류의 돌연변이를 모두 가지고 있는 triple mutant $\mathrm{MBL}$ 을 제작한 이유는 단일 돌연변이 보다 triple mutant MBL이 보다 현저한 현상을 나타 낼 것으로 기대하고 명확한 비정상적 생리 현상 증거를 우선 적으로 확보하기 위해서였다. 구축한 wild type과 triple mu$\operatorname{tant} \mathrm{MBL} \mathrm{DNA}$ 는 $\mathrm{HeLa}$ 와 $\mathrm{COS}$ 세포 내에서 정상적으로 작동 하여 각각의 단백질을 생산하였다. 동일한 vector로 구축하였 기 때문에 동일한 양의 단백질이 생산된 것으로 예상하였으며 western blot과 면역침강(immunoprecipitation) 법의 두 가지 방법 모두 비슷한 결과를 나타내어 정상 및 돌연변이 단백질 의 발현은 돌연변이와는 무관한 것으로 여겨진다. 그러나 과 발현한 상태에서 얻은 결과이므로 향후 발현되는 단백질을 생리적 농도로 낮추어 정상과 돌연변이 단백질 간에 순환율을 측정함으로써 돌연변이가 미치는 영향을 보다 정확히 알 수 있으리라 생각된다. 3 개의 돌연변이 도입으로 SDS-PAGE 상 
에서 mobility shift가 관찰되었는데, 이런 mobility shift는 인 산화 전후의 단백질에서 흔히 나타나는 현상으로 단백질에 음이온 수의 증가와 이로 말미암은 구조변형 등으로 나타나는 현상으로 생각된다.

Mannan-agarose를 사용한 MBL의 lectin 기능 검증 실험에 서는 wild type MBL 뿐만 아니라 triple mutant MBL 역시 mannan에 결합되어, $\mathrm{N}$-말단에 돌연변이가 있음에도 불구하 고 lectin의 기능은 정상임을 확인 할 수 있었다. 이같은 결과는 단일 점돌연변이 MBL 단백질 특성과 동일하였다. 따라서, mannan binding에 관여하는 C-말단 쪽 CRD domain의 구조 형성은 $\mathrm{N}$-말단 쪽에 있는 돌연변이에 의해 영향을 받지 않는 것으로 여겨진다. 형질전환 된 세포 배양 배지를 회수하여 wild type MBL과 triple mutant MBL 단백질의 세포 밖 분비 의 차이점을 관찰한 결과, triple mutant $\mathrm{MBL}$ 은 wild type $\mathrm{MBL}$ 과는 달리 세포 밖 분비가 전혀 되지 않음을 확인 할 수 있었다. Pulse-chase와 같은 실험을 통하여 보다 정확하게 조 사가 필요하지만, 단일 점돌연변이 $\mathrm{MBL}$ 의 경우 분비가 미약 하게 되고 triple mutant MBL 분비는 더욱 제한 된다고 생각 된다. 이 실험의 결과로 보아 $\mathrm{N}$-말단 쪽의 collagen 유사 domain은 lectin의 기능에는 영향을 미치지 않으나 $\mathrm{MBL}$ 의 분비 에 영향을 준다는 새로운 사실을 알 수 있었다. 면역 결핍증 환자의 혈청 내 MBL의 농도가 낮은 이유는 돌연변이 된 mu$\operatorname{tant} \mathrm{MBL}$ 이 세포 밖으로 분비 되지 않는다는 것을 재확인 할 수 있었다. Mutant MBL 단백질의 세포 밖 분비 이상은 세포 내 분비경로 과정 어디에서 문제가 있는지를 immunohistochemistry 방법으로 확인하였다. 분비경로가 시작되는 세포 내 소기관인 endoplasmic reticulum에서 Mutant MBL이 분비억제가 되고 축적되어 endoplasmic reticulum network가 심한 손상을 초래하였다. Mutant MBL에 의한 endoplasmic reticulum network의 손상 결과는 처음으로 밝혀지는 것으로 앞으로의 추가적인 연구와 더불어 mutant MBL의 세포 내 축 적에 의해 발생될 수 있는 세포 병리학 현상을 이해하는데 큰 기여를 할 것으로 기대된다.

\section{감사의 글}

이 연구는 2011년도 동의대학교 교내연구비 지원을 받아 수행되었습니다.

\section{References}

1. Agah, A., Montalto, M. C., Young, K. and Stahl, G. L. 2001. Isolation, cloning and functional characterization of porcine mannose-binding lectin. Immunology 102, 338-343.

2. Collard, C. D., Vakeva, A., Morrissey, M. A., Agah, A., Rollins, S. A., Reenstra, W. R., Buras, J. A., Meri, S. and Stahl, G. L. 2000. Complement activation after oxidative stress: role of the lectin complement pathway. Am J Patho 156, 1549-1556.

3. Drickamer, K., Dordal, M. S. and Reynolds, L. 1986. Mannose-binding proteins isolated from rat liver contain carbohydrate-recognition domains linked to collagenous tails. Complete primary structures and homology with pulmonary surfactant apoprotein. J Biol Chem 261, 6878-6887.

4. Ezekowitz, R. A. Day, L. E. and Herman, G. A. 1988. A human mannose binding protein is an acute-phase reactant that shares sequence homology with other vertebrate lectins. J Exp Med 167, 1034-1046.

5. Ezekowitz, R. A., Kuhlman, M., Groopman, J. E. and Byrn, R. A. 1989. A human serum mannose-binding protein inhibits in vitro infection by the human immunodeficiency virus. J Exp Med 169, 185-196.

6. Faure, E., Equils, O., Sieling, P. A., Thomas, L., Zhang, F. X., Kirschning, C. J., Polentarutti, N., Muzio, M. and Arditi, M. 2000. Bacterial lipopolysaccharide activates NF-kappaB through toll-like receptor 4 (TLR-4) in cultured human dermal endothelial cells. Differential expression of TLR-4 and TLR-2 in endothelial cells. J Biol Chem 275, 11058-11063.

7. Hansen, T. K. 2005. Mannose-binding lectin (MBL) and vascular complications in diabetes. Horm Metab Res 37, 95-102.

8. Hartshorn, K. L., Sastry, K., White, M. R., Anders, E. M., Super, M., Ezekowitz, R. A. and Tauber, A. I. 1993. Human mannose-binding protein functions as an opsonin for influenza A viruses. J Clin Invest 91, 1414-1420.

9. Hirano, M., Ma, B. Y., Kawasaki, N., Okimura, K., Baba, M., Nakagawa, T., Miwa, K., Oka, S. and Kawasaki, T. 2005. Mannan-binding protein blocks the activation of metalloproteases meprin alpha and beta. J Immunol 175, 31773185.

10. Hisano, S., Matsushita, M., Fujita, T., Endo, Y. and Takebayashi, S. 2001. Mesangia. IgA2 deposits and lectin pathway-mediated complement activation in IgA glomerulonephritis. Am J Kidney Dis 38, 1082-1088.

11. Hoffmann, J. A., Kafatos, F. C., Janeway, C. A. and Ezekowitz, R. A. 1999. Phylogenetic perspectives in innate immunity. Science 284, 1313-1318.

12. Honma, T., Kuroki, Y., Tsunezawa, W., Ogasawara, Y., Sohma, H., Voelker, D. R. and Akino, T. 1997. The mannose-binding protein A region of glutamic acid185-alanine221 can functionally replace the surfactant protein A region of glutamic acid195- phenylalanine228 without loss of interaction with lipids and alveolar type II cells. Biochemistry 36, 7176-7184.

13. Iwasaki, A. and Medzhitov, R. 2004. Toll-like receptor control of the adaptive immune responses. Nat Immunol 5, 987-995.

14. Janeway, C. A. Jr. and Medzhitov, R. 2002. Innate immune recognition. Annu Rev Immunol 20, 197-216.

15. Jensen, P. H., Weilguny, D., Matthiesen, F., Mcguire, K. A., Shi, L. and Hojrup, P. 2005. Characterization of the oligomer structure of recombinant human mannan binding lectin. $J$ Biol Chem 280, 11043-11051.

16. Kawai, T., Suzuki, Y., Eda, S., Ohtani, K., Kase, T., Sakamoto, 
T., Uemura, H. and Wakamiya, N. 1998. Molecular and biological characterization of rabbit mannan-binding protein. Glycobiology 8, 237-244.

17. Kielgast, S., Thiel, S., Henriksen, T. B., Bjerke, T., Olsen, J. and Jensenius, J. C. 2003. Umbilical cord mannan-binding lectin and infections in early childhood. Scand J Immund 57, 167-172.

18. Kilpatrick, D. C. 1998. Phospholipid-binding activity of human mannan-binding lectin. Immunol Lett 61, 191-195.

19. Kojima, M., Presanis, J. S. and Sim, R. B. 2003. The mannose binding lectin (MBL) route for activation of complement. Adv Exp Med Biol 535, 229-250.

21. Kuroki, Y., Honma, T., Chiba, H., Sano, H., Saitoh, M., Ogasawara, Y., Sohma, H. and Akino, T. 1997. A novel type of binding specificity to phospholipids for rat mannose-binding proteins isolated from serum and liver. FEBS Lett 414, 387-392.

22. Kwon, H. M., Park, J. A., Choi, B. T., Choi, Y. H. and Chung, K. T. 2009. Recombinant mannose-binding lectin protein and anti-mannose-binding lectin polyclonal antibody production. J Life Sci 19, 284-288.

23. Liu, H., Jensen, L., Hansen, S., Petersen, S. V., Takahashi, K., Ezekowitz, A. B., Hansen, F. D., Jensenius, J. C. and Thiel, S. 2001. Characterization and quantification of mouse mannan-binding lectins (MBL- $A$ and $M B L-C$ ) and study of acute phase responses. Scand I Immunol 53, 489-497.

24. Ma, Y., Uemura, K., Oka, S., Kozutsumi, Y., Kawasaki, N. and Kawasaki, T. 1999. Antitumor activity of mannan-binding protein in vivo as revealed by a virus expression system, mannan-binding protein dependent cell-mediated cytotoxicity. Proc Natl Acad Sci USA 96, 371-375.

25. Malhotra, R., Wormald, M. R., Rudd, P. M., Fischer, P. B., Dwek, R. A. and Sim, R. B. 1995. Glycosylation changes of IgG associated with rheumatoid arthritis can activate complement via the mannose-binding protein. Nat Med 1, 237-243.

26. Medzhitov, R. and Janeway, C. A. Jr. 2002. Decoding the patterns of self and nonself by the innate immune system. Science 296, 298-300.

27. Muto, S., Sakuma, K., Taniguchi, A. and Matsumoto, K. 1999. Human mannose-binding lectin preferentially binds to human colon adenocarcinoma cell lines expressing high amount of Lewis A and Lewis B antigens. Biol Pharm Bull
22, 347-352.

28. Palaniyar, N., Nadesalingam, J. and Reid, K. B. 2003. Innate immune collectins bind nucleic acids and enhance DNA clearance in vitro. Ann NY Acad Sci 1010, 467-470.

29. Palaniyar, N., Nadesalingam, J., Clark, H., Shih, M. J., Dodds, A. W. and Reid, K. B. 2004. Nucleic acid is a novel ligand for innate, immune pattern recognition collectins surfactant proteins A and D and mannose-binding lectin. $J$ Biol Chem 279, 32728-32736.

30. Peterslund, N. A., Koch, C., Jensenius, J. C. and Thiel, S., 2001. Association between deficiency of mannose-binding lectin and severe infections after chemotherapy. Lancet 358, 637-638.

31. Roos, A., Bouwman, L. H., van, Gijlswijk-Janssen D. J., Faber-Krol M. C., Stahl, G. L., and Daha, M. R. 2001. Human $\mathrm{IgA}$ activates the complement system via the mannan-binding lectin pathway. I Immunol 167, 2861-2868.

32. Sastry, K., Herman, G. A., Day, L., Deignan, E., Bruns, G., Morton, C. C. and Ezekowitz, R. A. 1989. The human mannose-binding protein gene. Exon structure reveals its evolutionary relationship to a human pulmonary surfactant gene and localization to chromosome 10. J Exp Med 170, 1175-1189.

33. Sheriff, S., Chang, C. Y. and Ezekowitz, R. A. 1994. Human mannose-binding protein carbohydrate recognition domain trimerizes through a triple alpha-helical coiled-coil. Nat Struct Biol 1, 789-794.

34. Takahashi, K., Ip, W. E., Michelow, I. C. and Ezekowitz, R. A. 2006. The mannose-binding lectin, a prototypic pattern recognition molecule. Curr Opin Immunol 18, 16-23.

35. Taylor, M. E., Brickell, P. M., Craig, R. K. and Summerfield, J. A. 1989. Structure and evolutionary origin of the gene encoding a human serum mannose-binding protein. Biochem J 262, 763-771.

36. Thorarinsdottir, H. K., Ludviksson, B. R., Vikingsdottir, T., Leopoldsdottir, M. O., Ardal, B., Jonsson, T., Valdimarsson, H. and Arason, G. J. 2005. Childhood levels of immunoglobulins and mannan binding lectin in relation to infections and allergy. Scand J Immunol 61, 466-474.

37. Weis, W. I., Drickamer, K. and Hendrickson, W. A. 1992. Structure of a C-type mannose-binding protein complexed with an oligosaccharide. Nature 360, 127-134. 
초록 : 돌연변이 Mannose-binding Lectin 합성과 세포 병리적 연구

장호정 · 정경태*

(동의대학교 임상병리학과)

선천성 면역은 감염성 매개체를 자기(self)로부터 변별할 수 있다. 선천성 면역은 감염 초기에 숙주인 자기를 보호하는 인식분자와 효과인자들로 구성되어 있다. Mannose 결합 렉틴(Mannose-binding lectin, MBL)은 $\mathrm{Ca}^{2+}$ 의존형 렉틴에 속하며, 콜라겐 유사 domain을 함유하는 C-type 렉틴으로 선천성 면역의 중요한 분자이다. 혈액 내 낮은 MBL 농도는 면역결핍 증후군을 나타내며 감염에 대한 심각한 위험성을 초래한다. 사람의 MBL 결핍증 은 coding 영역의 돌연변이에 의해 나타나며, 이 돌연변이의 영향을 연구하기 위해 쥐의 상동성 유전자인 $M B L-A$ 를 이용하고 있다. 돌연변이 MBL의 기능적, 세포 생리적 연구를 위해 선행연구에서 rat wild type $M B L-A$ 유전자 를 클로닝하였으며, 본 연구에서 이 유전자에 콜라겐 유사 domain에서 발견된 세 가지 돌연변이, R40C, G42D, G45E를 site-directed mutagenesis 방법으로 모두 도입하였다. 세 가지 돌연변이가 존재하는 MBL 단백질은 정상 $\mathrm{MBL}$ 과 마찬가지로 세포 내에서 정상적으로 발현되었으며, 여전히 렉틴 기능을 가지고 있었다. 이는 세 가지 돌 연변이가 렉틴 기능을 나타내는 C-말단 쪽의 carbohydrate recognition domain에는 구조적으로, 또한 기능적으로 도 영향을 미치지 않는다는 결과이다. 그러나 이 돌연변이는 MBL 단백질이 세포 밖으로 분비되는 것을 방해하였 으며, 그 결과로 소포체 내에 잔류하여 소포체 망상구조(endoplasmic reticulumn network)에 커다란 손상을 주며 비정상적인 형체를 초래하였다. 이 같은 결과는 돌연변이 MBL에 의해 나타난 세포 내 병리현상의 새로운 발견으 로 향후 MBL의 구조 형성과 분비 연구에 기여를 할 것으로 생각된다. 